\title{
Regeneracja zaworów silników okrętowych metodą napawania plazmowego
}

\author{
Marine engine valves plasma hard-facing regeneration
}

\section{Streszczenie}

W artykule przedstawiono zastosowanie procesu napawania plazmowego (PTA) do regeneracji zużytych przylgni zaworów wylotowych okrętowych silników Diesla. Zużyte zawory, po odpowiedniej selekcji, poddano obróbce skrawaniem w celu nadania odpowiedniego kształtu powierzchni przylgni, a następnie poddano procesowi napawania plazmowego z wykorzystaniem trzech rodzajów proszków na bazie kobaltu. Wybrane proszki charakteryzowały się wysoką zawartością chromu (ok. $30 \%$ ), niską zawartością niklu (ok. $2 \%$ ) oraz różnymi

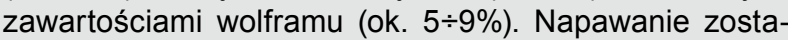
ło przeprowadzone automatycznie za pomocą urządzenia do napawania plazmowego proszkowego EUTRONIC GAP 200 firmy CASTOLIN. Po napawaniu zastosowano obróbkę skrawaniem w celu nadania wymaganej geometrii oraz gładkości powierzchni. Wykonano badania metalograficzne oraz pomiary mikrotwardości na powierzchni przylgni oraz na przekroju poprzecznym prostopadłym do powierzchni napoiny. Wytworzone warstwy wykazują budowę dendrytyczną, składającą się z roztworu stałego (zawierającego głównie kobalt, żelazo i nikiel) oraz eutektyki węglikowej (bogatej w wolfram, chrom i krzem). Warstwy wykonane z proszku o większej zawartości wolframu wykazały większą twardość na przekroju poprzecznym napoiny. Zastosowanie takiej metody regeneracji zaworów może wydłużyć czas ich eksploatacji.

\section{Wstęp}

Wiele współczesnych urządzeń, instalacji i ich elementów pracuje $w$ warunkach złożonych obciążeń $[1,2]$. Do takich urządzeń zaliczyć można elementy silnika Diesla służącego do napędu statków. Ich zawory

Dr inż. Hanna Smoleńska, dr hab. inż. Jerzy Łabanowski, prof. PG - Politechnika Gdańska, mgr inż. Włodzimierz Kończewicz - Akademia Morska w Gdyni. wydechowe są narażone na duże obciążenia mechaniczne o charakterze dynamicznym, pochodzące od ciśnienia spalania i wysokiej temperatury w silnie agresywnym ośrodku spalin. Obciążenia te znacząco wpływają na tempo zużycia zaworów. Szczególnie narażonya na zużycie jest stosunkowo wąski obszar styku grzybka zaworu z gniazdem zaworowym. Mimo stosowania do produkcji zaworów stali wysokostopowych obrobionych cieplnie ich trwałość jest niezadowalająca. Do najczęstszych uszkodzeń przylgni zaworów należą:

- nadpalanie brzegów grzybka spowodowane przepływem gorących gazów o wysokiej temperaturze przez nieszczelności (rys. 1a), 
a)
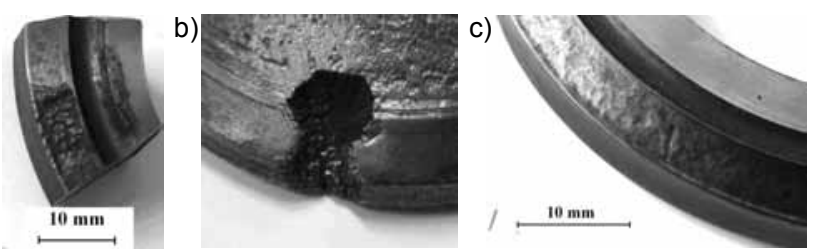

Rys. 1. Przykłady uszkodzeń przylgni zaworu wylotowego silnika okrętowego: a) korozja przylgni - „bruk”, b) zniszczenie przylgni i podłoża na skutek nieszczelności zaworu - nienaprawialne, c) zużycie przylgni - naprawialne

Fig. 1. Examples of marine engine exhaust valves damage: a) corrosion of valve face - „wear”, b) the destruction of the valve face and the valve substrate due to a valve leak - irreparable, c) wear of vaIve face - repairable

- utrata szczelności spowodowana wżerami korozyjnymi wywołana erozyjnym działaniem spalin (rys. 1b),

- pęknięcia, rysy i odpryski wywołane zmęczeniem warstwy wierzchniej przylgni (rys. 1c).

W celu przedłużenia trwałości zaworów możliwe jest zastosowanie umacniania przylgni za pomoca wytwarzania warstwy wierzchniej z materiału charakteryzującego się wyższą odpornością na zużycie oraz korozję niż materiał zaworu. Działanie takie może znaleźć zastosowanie w dwóch aspektach:

- wytwarzanie utwardzonej warstwy na nowych zaworach,

- regeneracja odpowiednio wyselekcjonowanych i przygotowanych zaworów uszkodzonych.

Celem podjętych badań był dobór optymalnego składu chemicznego proszku do wykonania napoiny na przylgni zaworu, która zapewni zachowanie odpowiedniej twardości, odporności na zużycie oraz agresywne działanie gazów spalinowych. Do wytworzenia warstwy wybrano metodę napawania plazmowego jako jedną z najbardziej nowoczesnych technologii wytwarzania warstw wierzchnich. Metodą tą można uzyskać powłoki z materiałów trudno topliwych i trudnościeralnych $[3 \div 5]$.

\section{Wytwarzanie warstw na przylgni zaworu}

Napawano plazmowo warstwy ze stopów kobaltu na podłożu zaworu wykonanego ze stali zaworowej H10S2M (X40CrSiMo10-2). W tablicy I przedstawiono skład chemiczny stali uzyskany w wyniku analizy spektralnej.

Napawanie plazmowe proszkowe - PTA, powierzchni przylgni prowadzono automatycznie za pomocą urządzenia do napawania plazmowego proszkowego EUTRONIC GAP 200 firmy CASTOLIN. Stanowisko do napawania wyposażono w sterowany numerycznie obrotnik, w którego uchwycie mocowano napawane zawory. W badaniach zastosowano proszki na osnowie kobaltu: EuTroLoy 16006, EuTroLoy 16012 oraz PG 5218. Ich skład chemiczny przedstawiono w tablicy II. Dobór proszków podyktowany był koniecznością jednoczesnego spełnienia dwóch podstawowych wymagań, tj. zapewnienia wysokiej odporności na ścieranie - stąd wybór stopów typu stellit - a jednocześnie zapewnienie wysokiej odporności na korozję w środowisku spalin. W przypadku silnika okrętowego liczyć się należy z możliwością stosowania paliw o zróżnicowanym składzie chemicznym, w tym także paliw ciężkich ze znaczna zawartością siarki. Takie warunki mogą być szkodliwe dla szeroko stosowanych stopów na bazie niklu ze względu na możliwe przyspieszone ich niszczenie w atmosferze zawierającej siarkę.

W celu ustalenia warunków technologicznych napawania przeprowadzono wstępne próby napawania ściegami po torze kołowym na krążkach ze stali X40CrSiMo10-2, symulując $w$ ten sposób proces napawania przylgni grzybka zaworu.

Wykonane napoiny próbne zostały poddane badaniom nieniszczącym w celu określenia ich jakości, przez co rozumiano brak pęknięć oraz gładkie i równe lico napoiny. Na podstawie badań wpływu parametrów napawania PTA na jakość i kształt napoin kołowych wykonanych na krążkach ze stali X40CrSiMo10-2 ustalone zostały podstawowe parametry procesu napawania (rys. 2, tabll. III). Próby napawania PTA $z$ ruchem wahadłowym palnika wykazały, że możliwe jest wykonanie warstw o wymaganej szerokości i kształcie, lecz w wyniku dużej energii liniowej napawania może

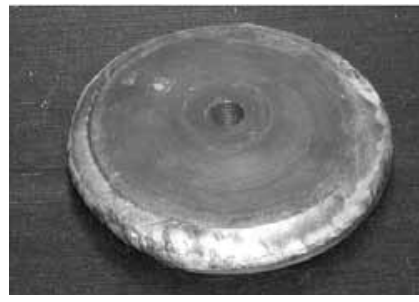

Rys. 2. Napoina jednowarstwowa składająca się z trzech ściegów wykonywana na krążku ze stali X40CrSiMo10-2

Fig. 2. One-layer three-bead padding weld on the $\mathrm{X} 40 \mathrm{CrSi}$ Mo10-2 steel disc

Tablica I. Skład chemiczny stali zaworowej (\% mas.)

Table I. Chemical composition of steel ( $\%$ mass)

\begin{tabular}{|l|c|c|c|c|c|c|c|c|}
\hline & $\mathrm{C}$ & $\mathrm{Cr}$ & $\mathrm{Mn}$ & $\mathrm{Ni}$ & $\mathrm{Si}$ & $\mathrm{Mo}$ & $\mathrm{P}$ & $\mathrm{S}$ \\
\hline H10S2M wg PN-71/H-86022 & $0,35 \div 0,45$ & $9 \div 10,5$ & $\max 0,7$ & $\max 0,5$ & $1,9 \div 2,6$ & $0,7 \div 0,9$ & $\max 0,035$ & $\max 0,030$ \\
\hline wg analizy chemicznej & 0,374 & 9,34 & 0,402 & 0,344 & 2,46 & 0,822 & 0,0162 & 0,001 \\
\hline
\end{tabular}

Tablica II. Skład chemiczny proszków stosowanych do napawania plazmowego (PTA) przylgni grzybków zaworów Table II. Chemical composition of powders used for PTA hard-facing of valves face

\begin{tabular}{|c|c|c|c|c|c|c|c|c|}
\hline \multirow{2}{*}{ Rodzaj proszku } & \multicolumn{8}{|c|}{ Skład chemiczny, \% mas. } \\
\hline & $\mathrm{C}$ & $\mathrm{Si}$ & $\mathrm{Cr}$ & W & $\mathrm{Ni}$ & Mo & $\mathrm{Fe}$ & Co \\
\hline EuTroLoy 16006 & 1,2 & 1,2 & 28,8 & 4,9 & 2,2 & $<0,1$ & 2,0 & reszta \\
\hline EuTroLoy 16012 & 1,55 & 1,21 & 29,7 & 9,0 & 2,0 & 0,01 & 1,7 & reszta \\
\hline PG5218 & 1,32 & 1,25 & 29,0 & 5,3 & 2,1 & $<0,1$ & 1,9 & reszta \\
\hline
\end{tabular}


Tablica III. Warunki technologiczne napawania PTA ściegów kołowych na krążkach ze stali X40CrSiMo10-2 [6]

Table III. Technological parameters of PTA hard-facing of ring beads on the X40CrSiMo10-2 steel discs [6]

\begin{tabular}{|l|c|}
\hline Natężenie prądu, A & $40 \div 60$ \\
\hline Natężenie przepływu gazu plazmowego, I/min & 3 \\
\hline Natężenie przepływu gazu ochronnego, I/min & $7 \div 8$ \\
\hline Natężenie przepływu gazu transportującego, l/min & 3 \\
\hline Natężenie podawania proszku, g/min & $10 \div 15$ \\
\hline Prędkość obrotowa stołu, obr/min & $0,8 \div 1,1$ \\
\hline
\end{tabular}
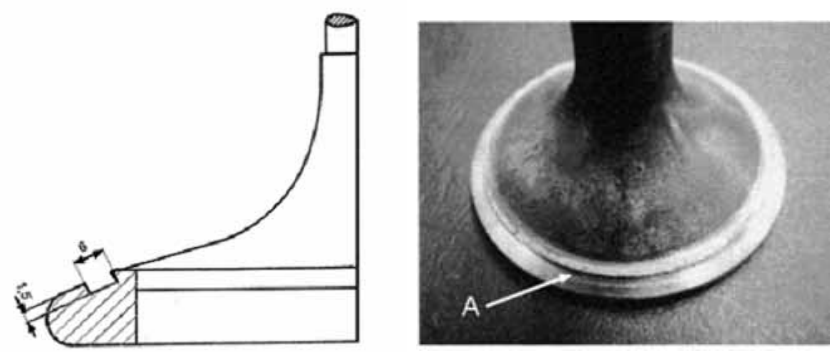

Rys. 3. Schemat i widok przygotowanej przylgni grzybka zaworowego do napawania plazmowego proszkowego PTA, A - wytoczenie przylgni

Fig. 3. Drawing and the view of valve face prepared for PTA powder hard-facing, $\mathrm{A}$ - turned groove

wystąpić nadmierne nagrzewanie grzybka zaworu i jego odkształcenie.

$\mathrm{Na}$ podstawie wstępnych prób napawania grzybków zaworów stwierdzono, że w celu zapewnienia wymaganego naddatku na obróbkę wykańczającą zaworów, konieczne jest wykonanie napoin o grubości $4,0 \div 4,5 \mathrm{~mm}$ i szerokości $9 \div 10 \mathrm{~mm}$. Takie wymiary napoin oraz konieczność ograniczenia wpływu ciepła napawania na grzybek zaworu o małej pojemności cieplnej wymagały wykonania PTA trzema warstwami zawierającymi trzy ściegi, z zakładką ściegów ok. $3 \mathrm{~mm}$. Proces napawania zaworów prowadzono $z$ podgrzewaniem wstępnym grzybka zaworu do temp. ok. $250^{\circ} \mathrm{C}$, a temperaturę międzyściegową utrzymywano na poziomie ok. $200^{\circ} \mathrm{C}$, w celu zapobieżenia pęknięciom poprzecznym napoiny. Opracowane warunki technologiczne zapewniają wykonanie ściegów o szerokości ok. $4 \mathrm{~mm}$ i grubości w zakresie 1,2 $\div 1,4 \mathrm{~mm}$. Parametry procesu napawania zaworów przedstawiono w tablicy IV. We wszystkich przypadkach zastosowano następujące warunki: gaz plazmowy - argon, gaz podający proszek i gaz ochronny mieszanka MIX 5 (argon $+5 \% \mathrm{H}_{2}$ ); odległość dyszy palnika od materiału $4 \div 5 \mathrm{~mm}$. Temperatura podgrzewania wstępnego $250^{\circ} \mathrm{C}$; temperatura międzyściegowa - min. $200^{\circ} \mathrm{C}$; wymiary ściegu to szerokość ok. $4 \mathrm{~mm}$ i grubość $1,2 \div 1,4 \mathrm{~mm}$.

Do wykonania napoin na zaworach zostały one odpowiednio przygotowane za pomocą obróbki skrawaniem. Powierzchnie przylgni przygotowano przez wykonanie podtoczenia o szerokości ok. $6 \mathrm{~mm}$ i głębokości ok. 1,5 mm. Schemat i zdjęcie przygotowanej powierzchni do napawania przedstawiono na rysunku 3.

Po napawaniu warstwa napoiny została obrobiona skrawaniem w celu nadania przylgni odpowiedniego kształtu i wymaganej gładkości.

\section{Ocena właściwości warstw napawanych}

W celu oceny właściwości otrzymanych warstw poddano je badaniom metalograficznym na mikroskopie optycznym oraz skaningowym mikroskopie elektronowym (SEM), analizom składu chemicznego $z$ wykorzystaniem przystawki EDS oraz pomiarom twardości na przekroju. Do analiz zawory zostały przecięte promieniowo i wykonano z nich próbki zgodnie ze schematem pokazanym na rysunku 4.

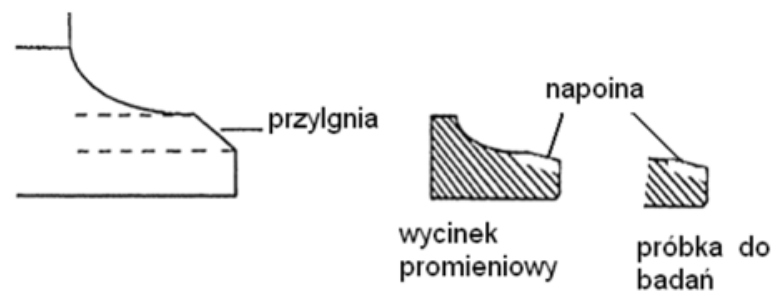

Rys. 4. Przygotowanie próbek do badań mikrostruktury i twardości Fig. 4. Samples preparation for microstructure and hardness testing

Tablica IV. Warunki technologiczne napawania PTA pojedynczych ściegów powierzchni roboczej grzybków zaworów ze stali X40CrSiMo10-2 [6] Table IV. Technological parameters of PTA hard-facing of single beads on the X40CrSiMo10-2 valve face [6]

\begin{tabular}{|c|c|c|c|c|c|}
\hline Rodzaj proszku & Warstwa napoiny & $\begin{array}{l}\text { Natężenie } \\
\text { prądu, A }\end{array}$ & $\begin{array}{l}\text { Natężenie przepływu } \\
\text { gazu ochronnego, l/min }\end{array}$ & $\begin{array}{l}\text { Natężenie przepływu gazu } \\
\text { transportującego, } 1 / \text { min }\end{array}$ & $\begin{array}{l}\text { Natężenie podawa- } \\
\text { nia proszku, g/min }\end{array}$ \\
\hline \multirow{3}{*}{ EuTroLoy 16006} & 1 & $40 \div 55$ & \multirow{3}{*}{7} & \multirow{3}{*}{3} & \multirow{3}{*}{$10 \div 12$} \\
\hline & 2 & $45 \div 55$ & & & \\
\hline & 3 & $45 \div 55$ & & & \\
\hline \multirow{3}{*}{ EuTroLoy 16012} & 1 & $45 \div 55$ & \multirow{3}{*}{7} & \multirow{3}{*}{3} & \multirow{3}{*}{$10 \div 12$} \\
\hline & 2 & $45 \div 60$ & & & \\
\hline & 3 & $45 \div 60$ & & & \\
\hline \multirow{3}{*}{ PG 5218} & 1 & $40 \div 45$ & \multirow{3}{*}{7} & \multirow{3}{*}{3} & \multirow{3}{*}{$10 \div 12$} \\
\hline & 2 & $45 \div 50$ & & & \\
\hline & 3 & $45 \div 50$ & & & \\
\hline
\end{tabular}




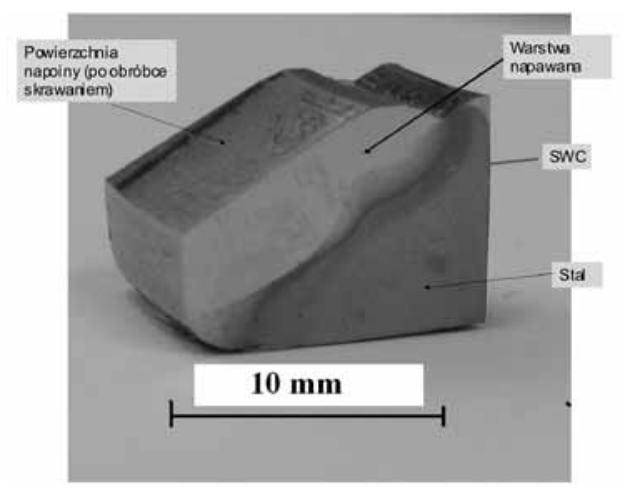

Rys. 5. Przekrój warstwy napawanej

Fig. 5. Cross-section of the padding weld
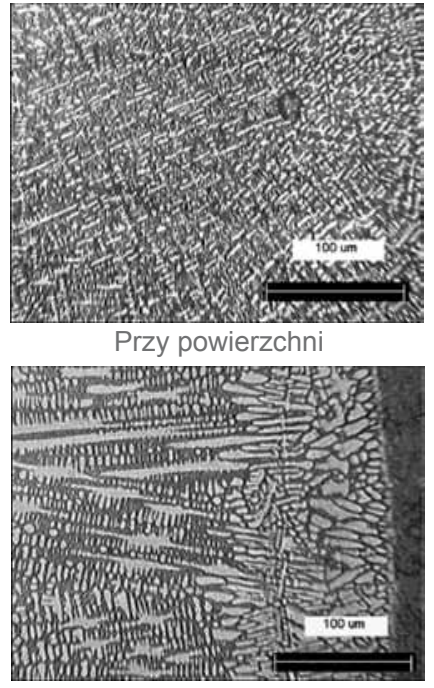

Granica napoina-stal
Przy powierzchni

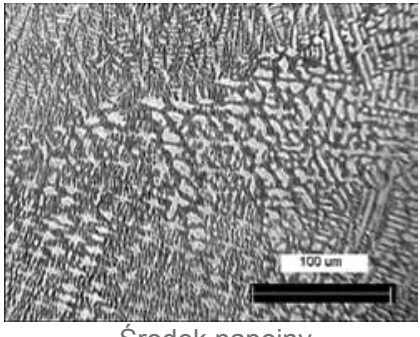

Środek napoiny

Rys. 6. SEM; mikrostruktura warstwy napawanej plazmowo wykonanej z proszku EuTroLoy 16006

Fig. 6. SEM; microstructure of PTA hard-facing layer made using the EuTroLoy 16006 powder

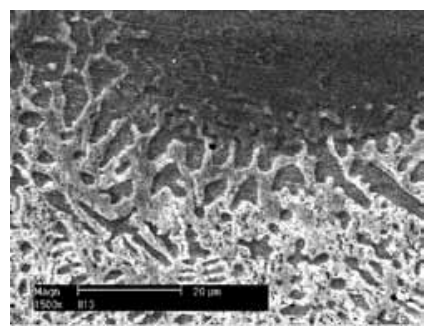

Rys. 7. SEM; mikrostruktura napoiny $\mathrm{w}$ miejscu nakładania się ściegów

Fig. 7. SEM; microstructure of weld metal in the beads boundary
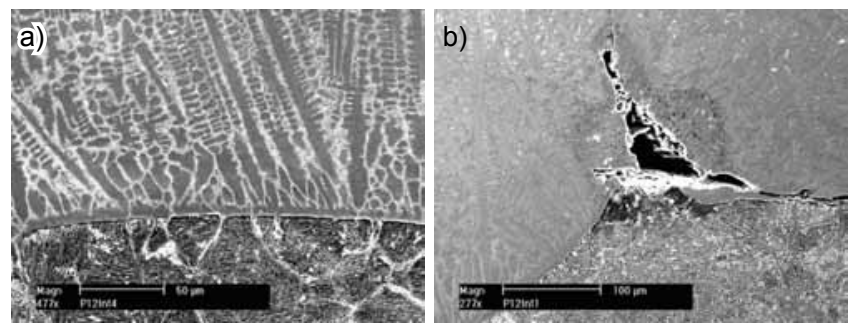

Rys. 8. SEM, mikrostruktura napoiny wykonanej z proszku EuTroLoy 16012: a) typowa mikrostruktura napoiny na granicy napoina-stal, b) nieciagłość na granicy napoina-stal

Fig. 8. SEM, microstructure of padding weld made using EuTroLoy 16012 powder: a) typical microstructure on the padding weld-steel boundary, b) padding weld-steel boundary discontinuity

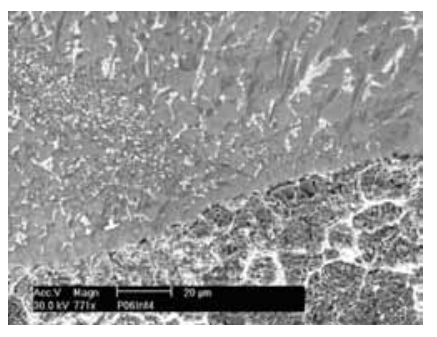

Rys. 9. SEM, mikrostruktura napoiny wykonanej z proszku EuTroLoy 16006; obszar linii wtopienia

Fig. 9. SEM, microstructure of padding weld made using EuTroLoy 16006; fusion line area

Na rysunku 5 przedstawiono fragment zaworu z napawaną przylgnią po przygotowaniu zgładu metalograficznego na powierzchni przecięcia prostopadłej do powierzchni napoiny. Wyraźnie widoczna jest granica między warstwą stopu kobaltu i podłożem stalowym, a także strefa wpływu ciepła.

Po procesie napawania mikrostruktury napoin wykazywały typowy charakter dendrytyczny, kierunkowy. Na rysunku 6 widoczne są obszary dendrytyczne $z$ austenitu kobaltowego umocnionego roztworowo przez chrom, wolfram i molibden. Eutektyki międzydendrytyczne i węgliki są bogate w chrom, wolfram i krzem. Analiza fazowa wykazała obecność węglików typu $\mathrm{M}_{12} \mathrm{C}\left(\mathrm{Co}_{6} \mathrm{~W}_{6} \mathrm{C}\right)$ i $\mathrm{M}_{23} \mathrm{C}_{6}\left(\mathrm{Cr}_{23} \mathrm{C}_{6}\right)[6 \div 9]$

Proces napawania prowadzi do zmian składu chemicznego na granicy napoina-stal, co jest konsekwencją procesu mieszania nadtopionego podłoża i stopionego proszku powłoki. Dodatkowy wpływ na strukturę i właściwości ma także technika wykonywania napoiny - wielościegowość z zakładką oraz wielowarstwowość, co prowadziło do ponownego nagrzewania gotowej warstwy podczas nakładania kolejnej warstwy i prowadziło do zmian w mikrostrukturze

a)
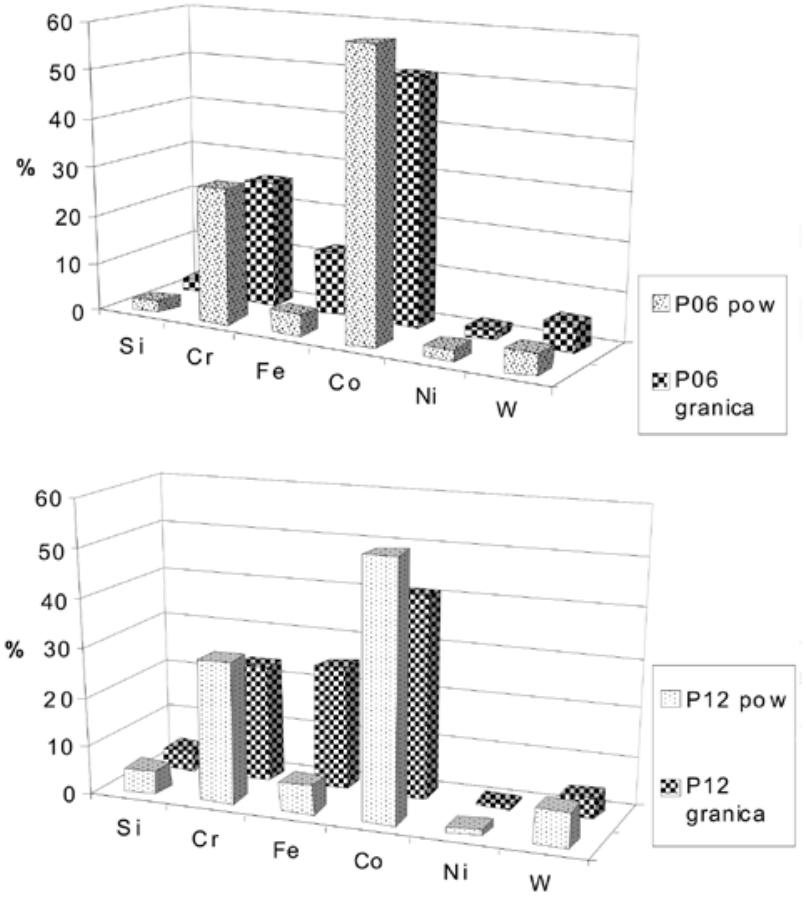

Rys. 10. Zmiany składu chemicznego napoiny (na powierzchni i przy linii wtopienia) z proszku: a) EuTroLoy 16006, b) EuTroLoy 16012

Fig. 10. Padding weld chemical composition changes (on the face and near to fusion line made using powder: a) EuTroLoy 16006, b) EuTroLoy 16012 
(rys. 6 i 7). Obszary na granicach między napoiną a stalą wykazywały zróżnicowane struktury, ale nieciągłości były rzadkością. Jedyny wykryty przypadek pokazano rysunku $8 b$.

Dla napoiny wykonanej z proszku EuTroLoy 16012 zaobserwowano stosunkowo niewielkie

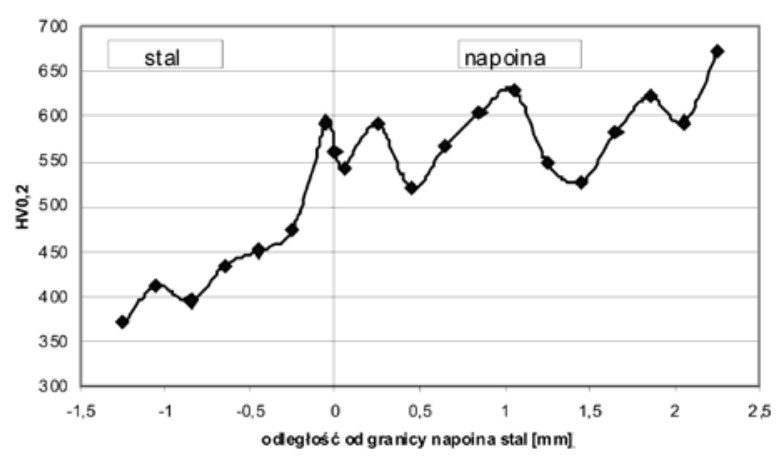

Rys. 11. Średnia wartość mikrotwardości napoiny na przekroju prostopadłym do powierzchni, wykonanej z proszku EuTroLoy 16006

Fig. 11. Average hardness distribution on the cross-section perpendicular to face of the padding weld made using EuTroLoy 16006 powder

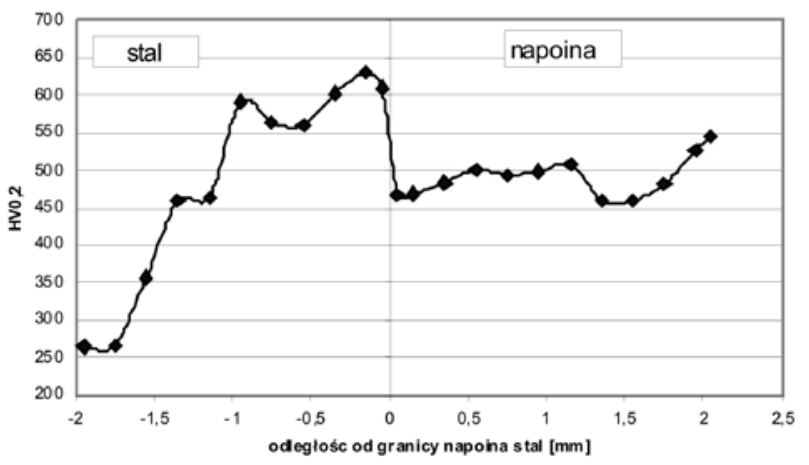

Rys. 12. Średnia wartość mikrotwardości napoiny na przekroju prostopadłym do powierzchni, wykonanej z proszku PG 5218

Fig. 12. Average hardness distribution on the cross-section perpendicular to face of the padding weld made using PG 5218 powder

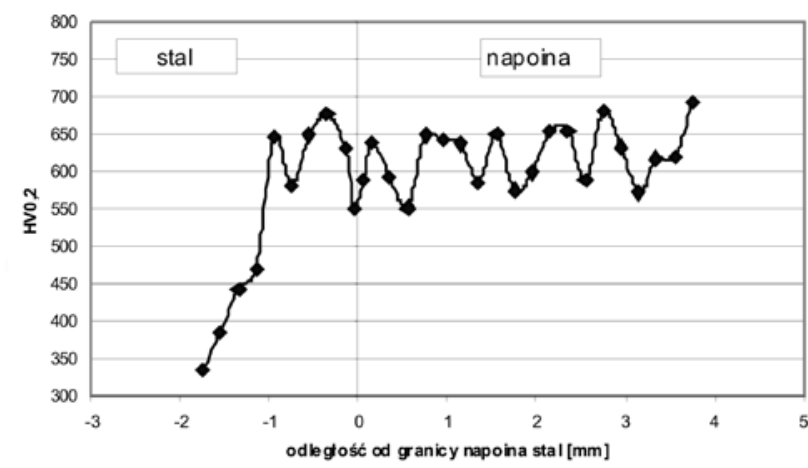

Rys. 13. Mikrotwardość na przekroju prostopadłym do powierzchni napoiny wykonanej z proszku EuTroLoy 160012

Fig. 13. Average hardness distribution on the cross-section perpendicular to face of the padding weld made using EuTroLoy 160012 powder zróżnicowanie, najczęściej występującą strukturę przedstawia rysunek $8 \mathrm{a}$. W odniesieniu do napoin wykonanych z pozostałych proszków mikrostruktury są bardziej różnorodne. Oprócz typowej struktury dendrytycznej ukierunkowanej, podobnej jak na rysunku 8a, zaobserwowano również liczne obszary o silnie zróżnicowanej wielkości i charakterze wydzieleń (rys. 9).

Za pomocą przystawki EDS, wykonano analizy składu chemicznego napoin w warstwie powierzchniowej i w pobliżu granicy napoina-stal, co pozwoliło na ocenę stopnia wymieszania materiałów podczas napawania. Przykładowe wyniki dla napoin wykonanych z proszków EuTroLoy 16006 oraz EuTroLoy 16012 przedstawiono na rysunku 10.

Badania wykazały zwiększoną zawartość żelaza w napoinach w stosunku do jego zawartości w proszku (ok. $2 \%$ ). W warstwach powierzchniowych napoin wzrost ten jest nieznaczny, jednakże w pobliżu granicy napoina-stal zawartość żelaza jest znacząco wyższa. Obserwuje się także różnice w rozkładzie pierwiastków w napoinach wykonanych różnymi proszkami. Większe zawartości żelaza na powierzchni napoiny oraz przy linii wtopienia obserwowano przy napawaniu proszkiem EuTroLoy 16012.

Do oceny właściwości napoin wykorzystano pomiar mikrotwardości na przekroju prostopadłym do powierzchni napoiny, od powierzchni do podłoża stalowego. Ze względu na niejednorodność struktury i składu chemicznego typowego dla struktur dendrytycznych rozkład twardości na przekroju napoiny nie jest monotoniczny, lecz charakteryzuje się dużą zmiennością. W celu ograniczenia wpływu znacznych różnic w twardości obszarów dendrytycznych i wydzieleń z obszarów międzydendrytycznych przeprowadzono pomiar w pięciu seriach, a na wykresach przedstawionych na rysunkach $11 \div 13$ podano tylko wartości średnie z pięciu serii pomiarowych.

Wyniki pomiarów twardości wskazują na zróżnicowane właściwości otrzymanych napoin. Cechą wspólną wszystkich warstw jest wystąpienie wzrostu twardości w podłożu stalowym w pobliżu granicy napoina-stal, co wskazuje na występowanie strefy wpływu ciepła. Jednakże maksymalne wartości oraz głębokość warstwy o zwiększonej twardości jest różna. Najmniejszy wzrost twardości i szerokości SWC zaobserwowano dla napoiny z proszku EuTroLoy 16006 (rys. 11) oraz EuTroLoy 16012 (rys. 13). Dla napoiny wykonanej z proszku PG 5218 (rys.12) zarówno wzrost twardości, jak i grubość warstwy o zwiększonej twardości były znaczne. Ponieważ celem procesu jest uzyskanie twardej warstwy na powierzchni przylgni, to wykorzystanie proszku EuTroLoy 160012 wydaje się najbardziej wskazane ze względu na najwyższą twardość uzyskanej napoiny, która zmienia się w zakresie 570 $\div 700 \mathrm{HV0,2}$. W pozostałych przypadkach uzyskano wartości niższe, odpowiednio $520 \div 670$ dla napoiny z proszku EuTroLoy 16006 i zaskakująco niskie wartości, 450 $\div 550$ dla napoiny wykonanej z proszku PG 5218. 


\section{Wnioski}

W wyniku przeprowadzonych badań stwierdzono, że:

- w celu zapewnienia wymaganej jakości i kształtu napoin konieczne jest napawanie trzywarstwowe, z ograniczeniem energii liniowej napawania;

- z uwagi na odmienne właściwości fizyczne badanych proszków na osnowie kobaltu, w przypadku napawania PTA konieczny jest dokładny dobór parametrów napawania, w zależności od rodzaju zastosowanego proszku;
- napawanie wielowarstwowe zapewnia istotne zmniejszenie ilości pierwiastków pochodzących z materiału rodzimego w warstwie wierzchniej napoiny;

- zastosowanie proszków o większej zawartości wolframu daje warstwy o wyższej twardości.

- napawane warstwy mają silnie ukierunkowaną strukturę dendrytyczną;

- w podłożu stalowym obserwuje się występowanie typowej strefy wpływu ciepła.

\section{Literatura}

[1] D'Oliveira A. S.C., Vilav R., Feder C.G.: High temperature behaviour of plasma transferred arc and laser Co-based alloy coatings; Applied Surface Science 201, 2002.

[2] D’Oliveira A.S.C., Da Silva P.S.C.P.: Microstructural features of consecutive layers of Stellite 6 deposited by laser cladding; Surface and Coatings Technology 153, 2002.

[3] De Mol Van Otterloo J.L., De Hosson J.Th.M.: Microstructural features and mechanical properties of cobalt-based laser coating; Acta Materalia, v 45, 3/1997.

[4] Yongqiang Yang: Microstructure and properties of laserclad high temperature wear-resistant alloys; Applied Surface Science 140, 1999.

[5] Jiang W. H., Guan H. R., Hu Z. Q., Developments of a heat treatment for a directionaly solidified cobalt-base superalloy, Metallurgical and Materials Transactions: A: Physical Metallurgy and Materials Science. Warrendale: Aug 1999. Vol. $30 \mathrm{~A}$, Iss. 8.

[6] Sprawozdanie z pracy naukowo-badawczej pt.: Opracowanie warunków technologicznych napawania laserowego i plazmowego proszkami na osnowie kobaltu, przylgni grzybków zaworów ze stali X40CrSiMo10-2 oraz wykonanie partii próbnej zaworów GRANT KBN - 015721 4TO8C 06224.

[7] Hejwowski T., Wroński A.: Wytwarzanie powłok odpornych na zużycie, Wydawnictwo Politechniki Lubelskiej, Lublin 2000.

[8] Smith W.M.: Surface Materials Processing. Second Edition, Backmann Verlag, Berlin-London-Paris-Warsaw, 2001.

[9] Yang F.M., Sun X.S., Guan H.R., Hu Z.Q.: High-Temperature Low- Cycle Fatigue Behaviour of K40S Cobalt-Base Superalloy, Metallurgical and Materials Transactions, Apr. 2003, 34A.

[10] D'Oliveira A.S.C.M., Paredes R.S.C., Santos R.L.C. Pulsed current plasma transferred arc hardfacing, Journal of Materials Processing Technology 171, 2006, s. 167-174.

[11] d'Oliveira A.S.C., Vilar R., Feder C.G.: High temperature behaviour of plasma transferred arc and laser Co-based alloy coatings, Applied Surface Science 201, 2002, s. 154-160.

[12] Zhao R., Barber G.C., Wang Y.S., Larson J.E.: Wear mechanism analysis of engine exhaust valve seats with a laboratory simulaton, Tribology Transactions; Apr 1997; 40, 2; ProQuest Science Journals, 2009.

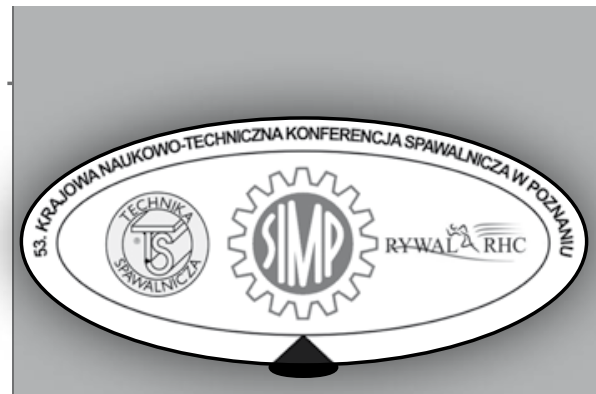

PATRONAT HONOROWY:

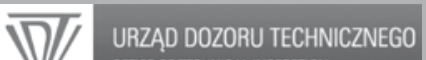
OFFICE OF TECHNICAL INSPECTION

PATRONAT MEDIALNY:

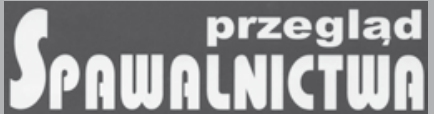
BULLEIYN
Mamy przyjemność zaprosić Państwa do uczestnictwa w

53. KRAJOWEJ NAUKOWO-TECHNICZNEJ KONFERENCJI SPAWALNICZEJ pt. „Nowe kierunki w procesach spajania i cięcia metali”

organizowanej w dniach 12 - 14 października 2011 r. w Poznaniu przez:

SIMP - SEKCJA SPAWALNICZA Oddział w Poznaniu

TECHNIKA SPAWALNICZA POZNAŃ, RYWAL RHC Spółka z o.o. w Warszawie $W$ programie $m$.in :

referaty z robotyki procesów spajania i cięcia

prezentacja nowych technologii i materiałów

referaty techniczne dotyczące $m$.in:

konstrukcji stalowej Stadionu Miejskiego w Poznaniu

konstrukcji iglicy Stadionu Narodowego w Warszawie

wyjazdy techniczne

VOLKSWAGEN POZNAŃ

STADION MIEJSKI

WYSTAWA URZADZEŃ I SPRZĘTU

POKAZY ROBOTÓW !

\section{ZAREZERWUJ SOBIE CZAS !}

W celu uzyskania szczegółowych informacji prosimy o kontakt: miroslaw.nowak@techspaw.com.pl andrzej.wisniewski@techspaw.com.pl ryszard.andrzejewski@techspaw.com.pl tel.: 602118401 ryszard.wesolowski@rywal.com.pl k.ptak@taskoprojekt.com.pl 